\title{
GEOMORPHOLOGY MAP OF KALAHANDI DISTRICT, ODISHA USING REMOTE SENSING AND GIS TECHNIQUES
}

\author{
Thabile Goitsemang*and Ch.Rajendra Subudhi** \\ *Ex M.Tech student,**Professor, Dept of SWCE, CAET,OUAT, \\ Bhubaneswar-751003, Odisha, India
}

\begin{abstract}
Groundwater has for a long time been a source of drinking water to urban and rural populations for both the developed and developing countries, therefore the understanding of the nature of this important resource, its potential zones, how much there is available, how long it may last in different places at current rates of extraction, is very important. With the use Geographic Information System (GIS) and remote sensing and technologies, groundwater potential zones mapping has become a less tedious procedure from the recent past, as the use of these techniques has offered a new avenue for groundwater availability assessment and identification of potential zones. For this present study, an attempt is made to identify groundwater potential zones in Kalahandi district, Odisha, India using remote sensing and GIS techniques at Dept of Soil and water conservation and Engineering, CAET, OUAT, Bhubaneswar during 2018-19. Flood plains which are considered as good groundwater prospect as much as the water bodies only cover slight patches of the total area of the study area, and also visible in patches are the anthropogenic terrain and dissected plateau which was obtained from geomorphology map of Kandhamal district of Odisha.
\end{abstract}

Key words-Geomorphology remote sensing GIS 


\section{INTRODUCTION}

Groundwater is without a doubt a precious resource especially in the arid and semi-arid areas and areas where there is limited availability of surface water. The global demand for water has seen a significant increase over the past years which mainly came as a result of industrialization, population growth and changing consumption patterns among other factors, and this dramatic increase is expected to continue to grow significantly over the foreseeable future with the outright scarcity becoming all but invertible. Climate change has also impacted the recharge and supply of the water resources putting more pressure in the available limited groundwater resources in many countries.

\section{Concept of Occurrence and Movement of Groundwater}

Hydrologists use the term groundwater to represent water in the zone of saturation; it is explained as the water found in the subsurface in fractures of rock formations and soil pore spaces. (Subramanya, 2013) defines it as the water from precipitation that has found its way to infiltrate the earth surface, recharge from streams and other natural bodies and artificial recharge due to the action of man. Groundwater is extracted from either consolidated rock formations or unconsolidated loose sediments and occurrence in both the rock formation is strikingly different. Two main properties of the rock; porosity and permeability are considered to control the occurrence of groundwater in a geological formation, its flow rate and its scope for exploitation (Lakshmi and Reddy 2018).

\section{Remote sensing and GIS in groundwater studies}

Assessment and potential zoning of groundwater using field observation are expensive and time-consuming, but with the use of remote sensing and Geographic Information System (GIS) technologies, the groundwater potential zones mapping within each geological unit has become less tedious and time-consuming (ALRuzouq et, al. 2015). From the recent past, the use of these techniques has offered a new advanced way for groundwater availability assessment and for the identification of potential zones. A number of studies have been carried out and others are on-going for the investigation of groundwater potential zones using the integration of remote sensing and GIS techniques which provides quite accurate results and indirectly provides ways of analysis of the role of some directly observable surface parameters like geomorphic features, geological structures and their hydrologic character for groundwater availability, (Pothiraj and Rajagopalan 2011), (Sahoo et, al. 2015).

\section{Remote Sensing and GIS in Groundwater Studies}

Remote sensing and Geographic Information System (GIS) are rapid and effective techniques as large information especially in inaccessible areas can be provided within short period of time for monitoring, assessing and management, Ramamoorthy et, al. (2014), remote sensing and GIS also aid groundwater 
studies in areas where there is few hydro geological data and limited previous investigations, Solomon and Quiel (2005). The work carried out by Preeja et, al. (2011) made more noticeable or prominent the expediency of geographic information system (GIS) and remote sensing applications in groundwater studies, as they used these techniques in Ithikkara River Basin (IRB), Kerala, India to identify of groundwater potential zones.

According to Bhuvaneswaran et, al. (2015) the collective use of GIS and remote sensing based potential zone analysis has brought a new path in this field. Thus, the combination of these two techniques has proved to be a powerful tool in understanding the groundwater behavior in any Therefore taking into consideration the enormous vitality of groundwater and the advantages of GIS and remote sensing in identifying groundwater potential zones, a study was carried out to identify groundwater potential zones in Kalahandi district, Odisha, India using remote sensing and GIS techniques with the following objectives:

\section{Objectives of the study:}

The study is to be accomplished with the following objectives:

1. To develop hydrogeological thematic maps of the study area

2. To identify and delineate groundwater potential zones using GIS technique area.

\section{MATERIALS AND METHODS}

\section{Study area}

Kalahandi district occupies the South-Western portion of Orissa and lies between North latitudes 19 $9^{\circ} 3^{\prime}$ and $20^{\circ} 45^{\prime}$ and East longitudes $82^{\circ} 18^{\prime}$ and $83^{\circ} 48^{\prime}$. On the north the district is bounded by bounded of Balangir and Nawapara districts, on the south is bounded by Rayagada district, Nawarangpur and Raipur (Chhatisgarh) districts on the west and on the east lie Rayagada and Boudh districts. The district extends over an area of $7920 \mathrm{Sq}$. Km and has its headquarters at Bhawanipatna town which stands almost to the Eastern border. Shown below is the map of the study area in Fig 1. 

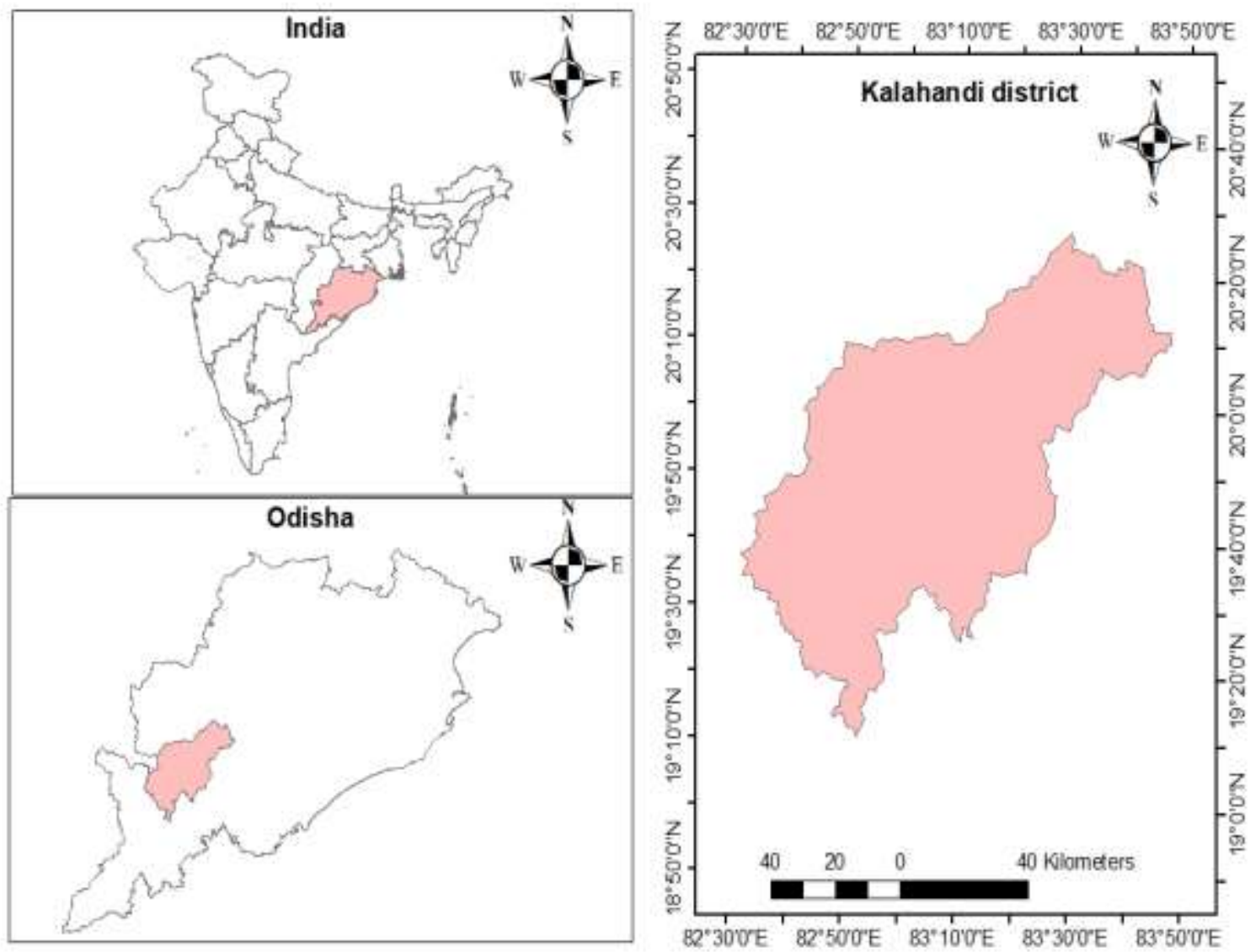

Fig 1 Location of the study area

\section{Topography}

The District can be classified into two distinct physiographic regions, which are the plain lands and the hilly tracts. The plain lands region run southward up to Bhawanipatna and then Westward through Junagarh and Dharmgarh and then further up to the boundary of the District, covering about 59 percent of the total area of the district. South Western part of Bhawanipatna subdivision is mostly covered by the hilly tracts, and some of the hilly tracts are covered with dense forest.

\section{Soils}

Different soil type's distribution in the district depends mainly on its physiographic and lithological variations. Based on the physical and chemical characteristics, mode of origin and occurrence, soils of the district may be classified into two groups namely Alfisols and Vertisols. Generally, the major soil type found in Kalahandi district is black soil with more clay content (Vertisols), matured unaltered soils with coarse parent materials (Entisols), red \& lateritic soil (Alfisols) mixed 
grey soil (Inceptisols) unclassified soil( like mud flats).

\section{Climate and rainfall}

The climate of the district is subtropical with hot and dry summer and pleasant winter. The summer season extends from March to the middle of June followed by the rainy season from June to September; the winter season extends from November till the end of February. There are large varieties of day and night temperature. Humidity is high during the middle of June and it's less in the postmonsoon period, the average relative humidity in the district varies from $27 \%$ to $80 \%$ throughout the year. It is dry except during monsoon and the south-west monsoon is the principal source of rainfall in the district. The average annual rainfall of the district is $1378.2 \mathrm{~mm}$. About 80 to $85 \%$ of the total rainfall is received during the period from June-September. The variation in the rainfall from year to year is not large. $90 \%$ of the rainfall received from June to September. Drought is a normal feature of this district.

\section{Groundwater scenario}

The hydrogeological framework of the district is mainly controlled by the geological setup, rainfall distribution and the degree of secondary and primary porosities in the geological formations for storage and movement of groundwater. Since major parts of the district are underlain by hard rocks of diverse lithological composition and structure, the water-bearing properties of the formations also vary to a great extent. A hydrogeological survey in the district reveals the lithological characteristics and the role of tectonic deformation on the occurrence and distribution of groundwater reservoirs and their waterbearing and water-yielding properties. Lineaments formed due to tensile deformation were picked up from remote sensing studies. The structural elements mainly control the occurrence and movement of groundwater in the typical fractured crystalline basement terrain. The major hydrogeologic units in the district are, areas underlain by fractured, fissured and consolidated basement rock formations and areas underlain by recent unconsolidated alluvial formations.

\section{RESULT AND DISCUSSION}

\section{Geomorphology map}

Geomorphology represents the landform and topography of an area, and is one of the main factors used widely for the delineation of groundwater potential zones (Arulbalaji et al 2018) and a geomorphologic map depict important geomorphic units, landforms and underlying geology so as to provide an understanding of the processes, materials/lithology, structures, and geologic controls relating to groundwater occurrence as well as to groundwater prospects (Machiwal et, al. 2011). Weathered and fractured hard rock terrains with higher elevations and steeper topography have medium to low groundwater potential, whereas floodplain zones are usually associated with good 
groundwater potential due to the high infiltration rates of the alluvium deposits (Thapa et, al. 2017) and by integrating geomorphologic background with hydrological characteristics of an area provides a simple way to understand the groundwater behavior (Siva et, al. 2017).

As Illustrated by fig 2 is the geomorphology map of the study area, the area has been divided into seven geomorphologic units which are anthropogenic terrain, denudational hills, and valleys, dissected plateau, flood plains, Pedi plain, structural hills and valleys and water bodies. The main geomorphic features of the study area are structural hills and valleys and Pedi plain which are considered poor in terms of groundwater prospecting. Predominant in the western side of the study area is the Pedi plain as the structural hills and valleys are occupying the majority of the eastern side. Water bodies are visible on the northern portion of the area and patches are also visible in the west and southwest areas. Flood plains which are considered as good groundwater prospect as much as the water bodies only cover slight patches of the total area of the study area, and also visible in patches are the anthropogenic terrain and dissected plateau

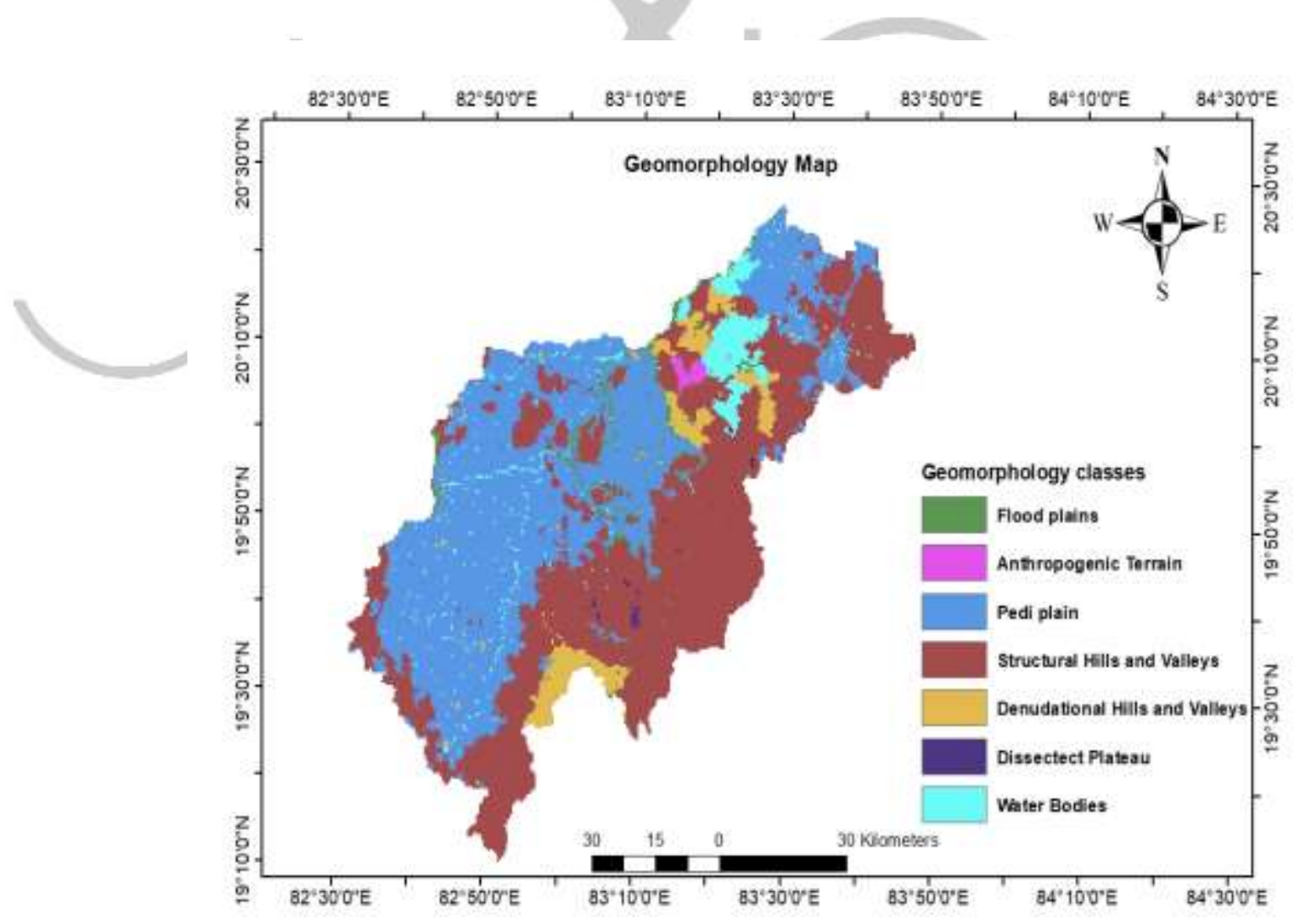

Fig 2 Geomorphology map of the study area 
In Table 1 the different zones of Kalahandi district of Odisha are shown in Table 1 and Fig 3 below and planning for digging LI point may be decided accordingly by any organization.

Table: 1 Potential zones area of individual blocks

\begin{tabular}{|c|c|c|c|c|c|c|}
\hline $\begin{array}{l}\text { SI. } \\
\text { No }\end{array}$ & Block name & $\begin{array}{l}\text { Very } \\
\text { good } \\
\left(\mathrm{km}^{2}\right)\end{array}$ & $\begin{array}{l}\text { Good } \\
(\mathrm{km} 2)\end{array}$ & $\begin{array}{l}\text { Moderate } \\
(\mathrm{km} 2)\end{array}$ & $\begin{array}{l}\text { Poor } \\
(\mathrm{km} 2)\end{array}$ & $\begin{array}{l}\text { Very } \\
\text { poor } \\
(\mathrm{km} 2)\end{array}$ \\
\hline 1 & Bhawaniptana & 43 & 296 & 297 & 243 & 43 \\
\hline 2 & Dharmagarh & 11 & 6 & 150 & 164 & 52 \\
\hline 3 & Golamunda & 34 & 91 & 303 & 130 & 83 \\
\hline 4 & Jaipatna & 6 & 49 & 148 & 53 & 255 \\
\hline 5 & Junagarh & 23 & 41 & 307 & 260 & 22 \\
\hline 6 & Kalampur & 6 & 2 & 108 & 14 & 24 \\
\hline 7 & Karlamunda & 4 & 5 & 30 & 3 & 154 \\
\hline 8 & Kesinga & 48 & 118 & 88 & 175 & 40 \\
\hline 9 & Kokasara & 9 & 25 & 356 & 97 & 5 \\
\hline 10 & Lanjigarh & 99 & 434 & 55 & 390 & 9 \\
\hline 11 & Madanpur & 19 & 7 & 323 & 164 & 331 \\
\hline & & $=$ & & & & \\
\hline 12 & Narala & 144 & 171 & 90 & 91 & 30 \\
\hline 13 & Thuamul Rampur & 5 & 252 & 416 & 423 & 20 \\
\hline
\end{tabular}




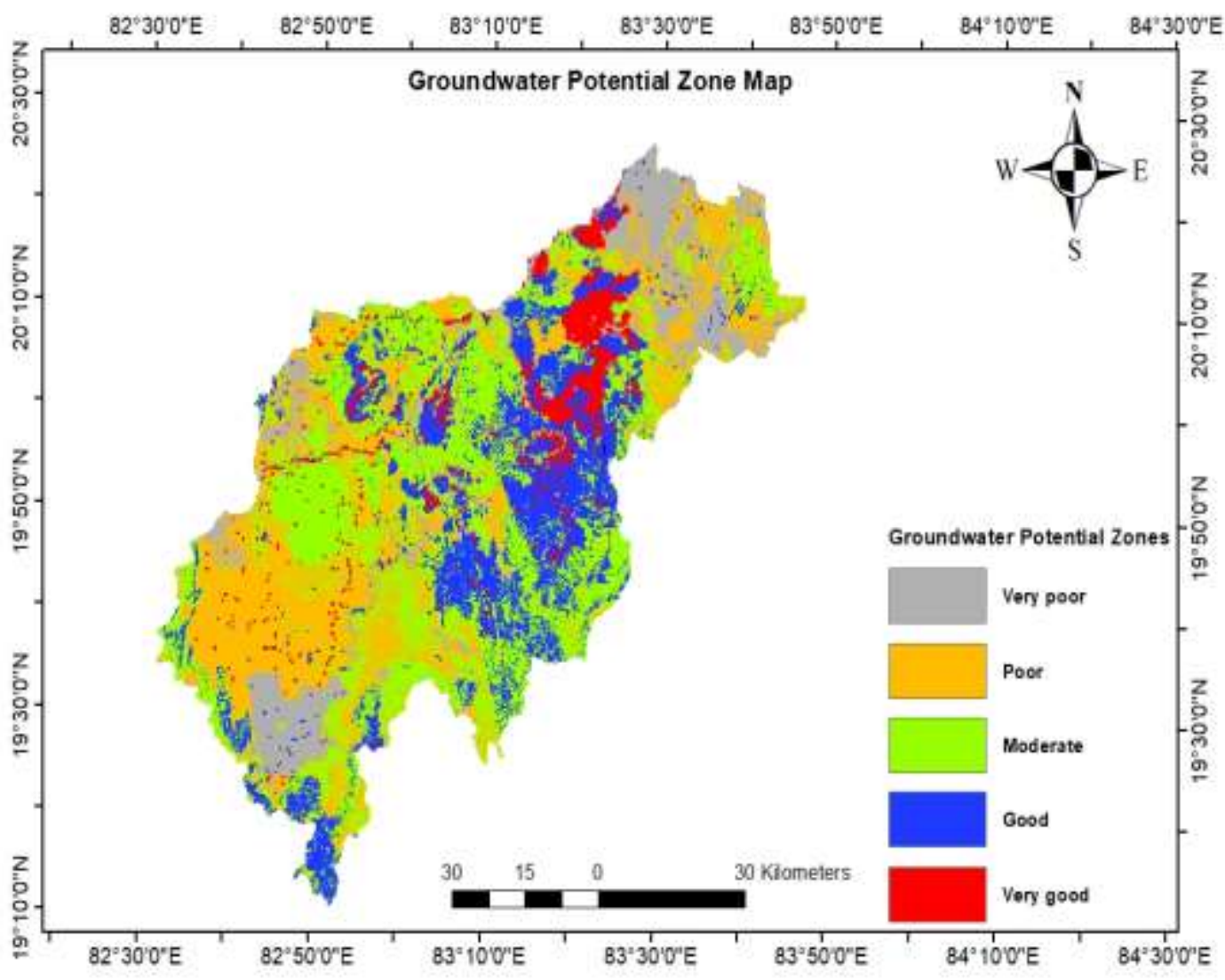

Fig 3 Groundwater potential zone map

\section{CONCLUSION}

1. Large areas of very poor groundwater potential zones are seen in the Karlamunda, Jaipatna and Madanpur Rampur blocks, whereas Narala block has the largest area covered by very good groundwater potential zone.

2. Flood plains which are considered as good groundwater prospect as much as the water bodies only cover slight patches of the total area of the study area, and also visible in patches are the anthropogenic terrain and dissected plateau.

\section{REVIEW OF LITERATURE}

AL-Ruzuoug R, Shanableh A and Merabtene T. 2015. Geomatics for Mapping of Groundwater Potential Zones in Northern Part of the United Arab EmiratisSharjah City, The International Achieves of the Photogrammetry, Remote Sensing and Spatial Information Sciences, $36^{\text {th }}$ International Symposium on Remote Sensing of Environment, Volume XL-7/W3, 581-586.

Bhuvaneswaran C, Ganesh A and Nevedita S. 2015. Spatial Analysis of 
Groundwater Potential zones using Remote Sensing, GIS and MIF Techniques in UpparOdai Sub-watershed, Nandiyar, Cauvery basin, Tamil Nadu, International Journal of Current Research7(9): 2076520774.

Lakshmi SV and Vinay Kumar Reddy Y. 2018. Identification of groundwater potential zones using GIS and remote sensing, International Journal of Pure and Applied Mathematics, 119(17):3195-3210.

Machiwal D, Jha MK and Mal BC. 2011. Assessment of Groundwater Potential in a Semi-Arid Region of India Using Remote Sensing, GIS and MCDM Techniques, Water Resour Manage25:1359-1386.

Pothiraj P and Rajagopalan B. 2011. A GIS and remote sensing based evaluation of groundwater potential zones in a hard rock terrain of Vaigai sub-basin, India, Arabian Journal of Geosciences: 1-18.

Preeja KR, Joseph S, Thomas J and Vijith H. 2011. Identification of Groundwater Potential Zones of a Tropical River Basin (Kerala, India) Using Remote Sensing and GIS Techniques, Journal of the Indian Society of Remote Sensing, 39(1): 83-94.

Ramamoorthy P, Arjun A, Gobinath K, Senthil Kumar $V$ and Sudhakar D. 2014. Geo Spatial Analysis of Groundwater
Potential Zone Using Remote Sensing and GIS Techniques in Varahanadhi Sub-basin, Tamilnadu, International Journal of Science, Engineering and Technology, 2(4): 273-285.

Sahoo S, Jha MK, Kumar $N$ and Chowdary VM. 2015. Evaluation of GIS-based multicriteria decision analysis and probabilistic modelling for exploring groundwater prospect, Environmental earth sciences.

Siva G, Nasir N and Selvakumar R. 2017. Delineation of Groundwater Potential Zone in Sengipatti for Thanjavur District using Analytical Hierarchy Process, IOP Conference Series: Earth and Environmental Science, 80 01206:1-14.

Solomon S and Quiel F. 2005. Groundwater study using remote sensing and geographic information systems (GIS) in the central highlands of Eritrea, Hydrogeology Journal14: 729-741.

Subramanya K. 2013. Engineering Hydrology. 4th edition, McGraw Hill Education Private Limited, India, 389.

Thapa R, Gupta S, Guin S and Kaur H. 2017. Assessment of groundwater potential zones using multi-influencing factor (MIF) and GIS: a case study from Birbhum district, West Bengal, Appl Water Sci, 7:4117-4131. 